MILleR, J. D., AND C. J. LIMPUS. 1981. Incubation period and sexual differentiation in the green turtle Chelonia mydas L. In C. B. Banks and A. A. Martin (eds.), Proc. Melbourne Herpetol. Symp., pp. 6673. Zool. Board Victoria, Parkville, Victoria.

MOLL, E. O., AND J. M. LeGLER. 1971. The life history of a neotropical slider turtle, Pseudomys scripta (Schoepff), in Panama. Bull. Los Angeles County Mus. Nat. Hist. Sci. 11:577-586.

Muth, A. 1980. Physiological ecology of desert iguana (Dipsosaurus dorsalis) eggs: temperature and water relations. Ecology 61(6):1335-1343.

- 1981. Water relations of desert iguana (Dipsosaurus dorsalis) eggs. Physiol. Zool. 54(4):441-451.

Newman, D. G., AND P. R. Watson. 1985. The contribution of radiography to the study of the reproductive ecology of the tuatara, Sphenodon punctatus. In G. Grigg, R. Shine, and H. Ehmann (eds.), Biology of Australasian Frogs and Reptiles, pp. 710. Surrey Beatty and Sons Pty Ltd. Chipping Norton, N.S.W.

PACKARD, G. C., C. R. TRACY, AND J. J. Roth. 1977. The physiological ecology of reptilian eggs and embryos, and the evolution of viviparity within the Class Reptilia. Biol. Rev. 52:71-105.

- M. J. PACKARD, AND W. H. N. GUTZKE. 1985. Influence of hydration of the environment on eggs and embryos of the terrestrial turtle Terrapene ornata. Physiol. Zool. 58:564-575.

— AND —. 1988. Physiological ecology of reptilian eggs and embryos. In C. Gans and R. B. Huey (eds.), Biology of the Reptilia, Vol. 16, pp. 523-605. Wiley, New York.

PACKARD, M. J., G. C. PACKARD, AND T. J. BOARDMAN. 1980. Water relations of eggs of a desert lizard (Callisaurus draconoides). Can. J.Zool. 58:2051-2058.

- $\longrightarrow$, AND W. H. N. GUTZKE. 1984. Calcium metabolism in embryos of the oviparous snake Coluber constrictor. J. Exp. Biol. 110:99-112.

$\longrightarrow,-$ J. D. MilleR, M. E. JONES, AND W. H. N. GUTZKE. 1985. Calcium mobilization, water balance, and growth in embryos of the agamid lizard Amphibolurus barbatus. J. Exp. Zool. 235:349357.

SAWYER, W. H. 1977. Evolution of active neurohypophysial principles among vertebrates. Amer. Zool. 17:727-737.

THOMPSON, M. B. 1990. Incubation of eggs of tuatara, Sphenodon punctatus. J. Zool., Lond. 222:303-318.

TRACY, C. R. 1980. Water relations of parchmentshelled lizard (Sceloporus undulatus) eggs. Copeia 1980(3):478-482.

YNTEMA, C. L. 1964. Procurement and use of turtle embryos for experimental procedures. Anat. Rec. 149:577-586.

-1968. A series of stages in the embryonic development of Chelydra serpentina. J. Morphol. 125:219-251.

- 1976. Effects of incubation temperatures on sexual differentiation in the turtle, Chelydra serpentina. J. Morphol. 150:453-462.

- AND N. MrosovsKY 1980. Sexual differentiation in hatchling loggerheads (Caretta caretta) incubated at different controlled temperatures. Herpetologica 36(1):33-36.

Accepted: 11 July 1990.
Journal of Herpetology, Vol. 25, No. 1, pp. 104-107, 1991

Copyright 1991 Society for the Study of Amphibians and Reptiles

\section{The Taxonomic Status of the Pleistocene Turtle Geoclemys sivalensis}

INDRANEIL DAS, Madras Crocodile Bank Trust, Vadanemmeli, Perur Post, Mahabalipuram Road, Madras 603 104, India.

The genus Geoclemys is known from the Plio-Pleistocene to recent times. Only one species, G. hamiltonii, described by Gray (1831), with numerous synonyms, is considered valid. Tewari and Badam (1969) described a fossil turtle, Geoclemys sivalensis, from the Upper Siwaliks of Punjab, in northern India. The present paper re-evaluates the taxonomic status of this fossil material, based on the published description and illustrations provided by Tewari and Badam (1969), and on photographs provided by Prof. Ashok Sahni, Punjab University. The material is preserved in the Museum of the Centre of Advanced Study in Geology (MCASG), Punjab University, Chandigarh (Reg. No. A/665).

Recent examples of Geoclemys hamiltonii with which the fossil of $G$. hamiltonii was compared were examined at the National Zoological Collection, Zoological Survey of India (ZSI), Calcutta; the Madras Crocodile Bank Trust (MCBT), Madras; and the British Museum (Natural History) (BM[NH]), London. Fossil materials were studied at the Geological Survey of India (GSI), Calcutta. Scute and bone terminology follows Zangerl (1969).

Geoclemys sivalensis was described by Tewari and Badam in 1969 (description republished by Badam in 1979), based on an incomplete shell from the Pinjor stage of the Upper Siwaliks (basal Pleistocene), $1 \mathrm{~km}$ SE of Quranwalla, Punjab, India.

The type specimen (MCASG A/665) is an incomplete shell (Fig. 1). Preserved parts of the carapace include vertebrals 1 and 2 (both entire), vertebral 3 (partial), pleural 1 (both left and right entire), pleural 2 (left and right partial), four left and three (?) right anterior marginals (mostly damaged on the free ends), and a cervical (partially damaged anteriorly). Plastral characters that are discernible include the following preserved scutes: left pectoral, left abdominal, left femoral, and two left marginals. In addition, the right hyoplastral and right hypoplastral bones are exposed. Head and limb bones are not preserved.

Tewari and Badam (1969) gave the estimated shell measurements (carapace length and width) as 23 and $21.5 \mathrm{~cm}$, respectively. However, based on the restored shell (Fig. 2A, B) my estimates are as follows: straight carapace length (SCL; distance between cervical at restored carapace midline to posterior-most point of the 12 th marginal $)=33 \mathrm{~cm}$; straight carapace width (SCW; distance across widest part of restored carapace, perpendicular to the longitudinal body axis) = $21 \mathrm{~cm}$; and plastron length (PL; distance between the anterior-most tip of the gulars and the posterior-most tip of the anals) $=28 \mathrm{~cm}$. The shell height, $\mathrm{SH}$, of the fossil material has been given as $9.5 \mathrm{~cm}$ in the type description. 